\title{
Do patients take digoxin?
}

\author{
G. D. JOHNSTON, J. G. KELLY, AND D. G. McDEVITT
}

From Belfast City Hospital and Department of Therapeutics and Pharmacology, The Queen's University of Belfast

Plasma digoxin concentrations on admission to hospital have been compared with levels on day 8 in a group of 50 patients who were maintained on their preadmission digoxin doses for 7 days. In the absence of a change in renal function, 18 patients (36\%) had higher levels on day 8 and were considered to be non-compliant: a further 7 patients (14\%) had lower levels on day 8 suggesting that before admission they had been taking more than their prescribed digoxin dose. Fifty per cent were, therefore, taking their digoxin improperly. In addition, an incorrect dose of digoxin may have been prescribed in 14 patients (28\%) with plasma digoxin concentrations either below $0.8 \mathrm{ng} / \mathrm{ml}(1.02 \mathrm{nmol} / \mathrm{l})$ or above $2.0 \mathrm{ng} / \mathrm{ml}(2.56 \mathrm{nmol} / \mathrm{l})$ on day 8 . Long-term compliance was assessed by comparing day 8 'steady state' digoxin levels with those obtained at outpatient follow-up. Thirty of the original group were studied at 4 weeks when 27 per cent were considered non-compliant, and 20 at 3 months when 30 per cent were non-compliant. These results have serious implications both for drug prescribing and for the treatment of disease, and suggest that a problem of communication exists between doctors and their patients.

In a previous study of patients already taking digoxin when admitted to hospital as emergencies (Carruthers et al., 1974), it was found that only 42 per cent had plasma digoxin concentrations within the normal therapeutic range of 0.8 to $2.0 \mathrm{ng} / \mathrm{ml}$ (1.02-2.56 nmol/1) (Whiting et al., 1973); 33 per cent had levels below $0.8 \mathrm{ng} / \mathrm{ml}(1.02 \mathrm{nmol} / \mathrm{l})$ and were presumably under-treated and 25 per cent had levels greater than $2.0 \mathrm{ng} / \mathrm{ml}(2.56 \mathrm{nmol} / \mathrm{l})$ and may have been potentially at risk from digoxin toxicity (Chamberlain et al., 1970; Whiting et al., 1973). Factors responsible for the wide scatter of digoxin concentrations were not identified. A further group of patierits have now been studied in which serial inpatient and outpatient plasma digoxin concentrations were used to investigate non-compliance as a possible explanation of the fact that so many levels lie outside the 'therapeutic range'.

\section{Patients and methods}

Consecutive patients admitted as emergencies to a general medical ward in the Belfast City Hospital and receiving maintenance digoxin treatment before admission were studied. For each patient, a careful history relating to digoxin treatment was taken with particular reference to the dose, the Received for pub ication 10 January 1977 timing of the last dose before admission, and the presence or absence of subjective symptoms of toxicity. The reason for each admission was also noted, especially whether cardiac disease had been a precipitating factor. Patients were asked if they had been taking their medication as prescribed and information was obtained about the total number of other tablets taken each day. A 12-lead electrocardiogram was recorded in each patient soon after admission and a blood sample taken for estimation of plasma digoxin, urea, creatinine, and serum potassium concentrations.

In the absence of digoxin toxicity, each patient was treated for 7 days with his preadmission digoxin dosage which, assuming the elimination half-life of digoxin to be 1.6 days (Jelliffe, 1968), should have enabled him to reach 'steady-state' plasma digoxin concentration. At the end of this treatment period and again where possible at 4 weeks and 3 months after discharge from hospital, the electrocardiogram and laboratory tests were repeated. On admission, blood samples for digoxin assay were taken at least 6 hours and less than 14 hours after the last digoxin dose. Blood samples at day 8,4 weeks, and 3 months were taken 6 to 8 hours after the last dose.

On the basis of plasma digoxin concentrations at day 8 digoxin dosage was adjusted where necessary before discharge from hospital using a nomogram 
Table 1 Manifestations of digoxin toxicity in 5 patients on day 1 and in 1 patient between day 1 and day 8

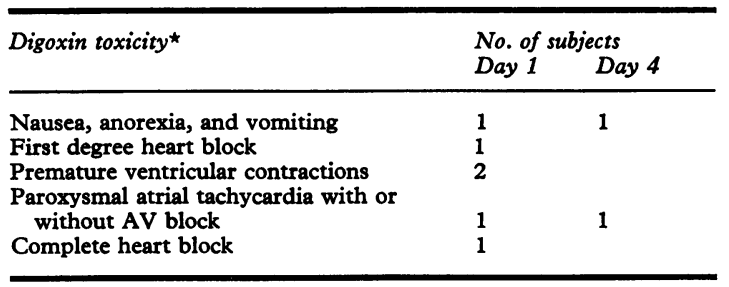

$\star_{2}$ subjects had more than one manifestation of toxicity.

(G. E. Mawer, R. Ahmad, S. B. Lucas, J. G. McCough, R. M. Stirland, and J. A. Tooth, 1974, unpublished observations).

Plasma digoxin levels were measured by radioimmunoassay using a modified Wellcome Lanoxitest $\beta$ kit method (Ojala et al., 1972). Results are shown as the mean \pm standard deviation. Statistical analyses were carried out using Student's paired $t$ test and the $\chi^{2}$ test.

\section{Results}

Sixty consecutive patients were studied after emergency admission to hospital. Of these, 5 patients were showing signs of digoxin toxicity on admission and 1 further patient developed these on day 4 . The manifestations of the digoxin toxicity are shown in Table 1. The mean plasma digoxin concentration in these patients was $2.68 \pm 1.03 \mathrm{ng} / \mathrm{ml}(3.43 \pm 1.32$

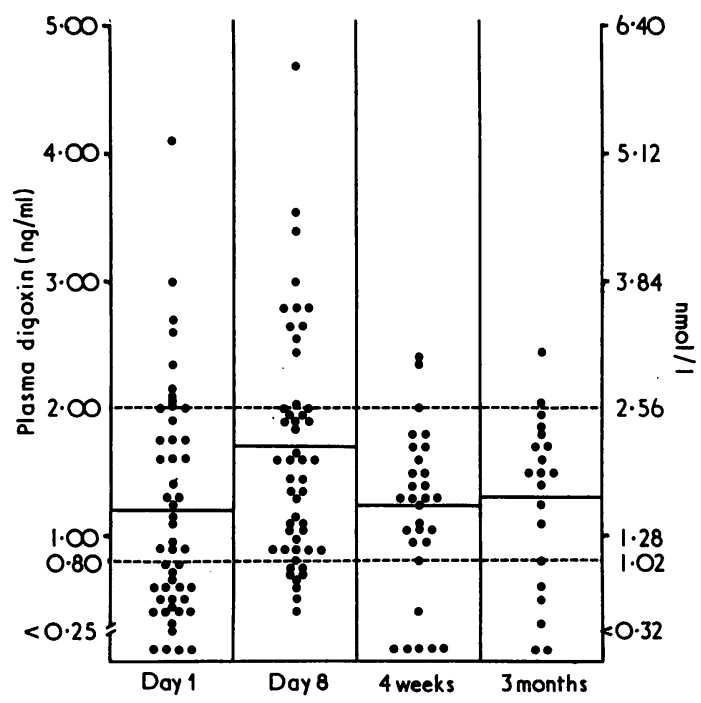

Fig. 1 Plasma digoxin concentrations obtained in patients on admission to hospital (50 patients), day 8 (50), 4 weeks after discharge (30), and 3 months after discharge (20). Mean levels are shown by horizontal lines, and dotted lines show limits of therapeutic range of concentrations.

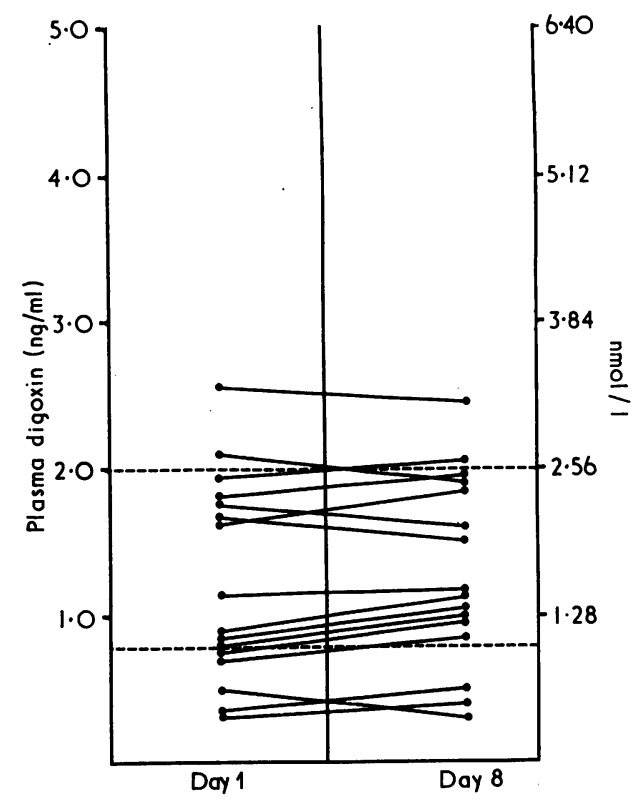

Fig. 2 Plasma digoxin concentrations in 16 patients whose levels did not change from day 1 to day 8.

nmol/l) and the symptoms and signs subsided after the drug was discontinued. Four patients died between day 1 and day 8 from causes not attributable to digoxin toxicity, leaving a total of 50 patients in the study. There were 23 men and 27 women and the mean age was $69.6 \pm 9.9$ years.

The plasma digoxin concentrations on admission, on day 8 , at 4 weeks after discharge (30 patients), and after 3 months (20 patients) are shown in Fig. 1 . The mean plasma digoxin concentration on admission was $1.19 \pm 0.85 \mathrm{ng} / \mathrm{ml}(1.52 \pm 1.09 \mathrm{nmol} / \mathrm{l})$ and this rose significantly to $1.70 \pm 0.92 \mathrm{ng} / \mathrm{ml}$ $(2.18 \pm 1.18 \mathrm{nmol} / \mathrm{l})$ by day $8(\mathrm{t}=3.58 ; \mathrm{P}<0.001)$. Of the group of 50 patients, 22 had plasma digoxin concentrations on admission below $0.8 \mathrm{ng} / \mathrm{ml}$ $(1.02 \mathrm{nmol} / \mathrm{l}), 19$ had levels of 0.8 to $2.0 \mathrm{ng} / \mathrm{ml}$ $(1.02$ to $2.56 \mathrm{nmol} / \mathrm{l})$, and the remaining $9 \mathrm{had}$ levels greater than $2.0 \mathrm{ng} / \mathrm{ml}(2.56 \mathrm{nmol} / \mathrm{l})$. After 7 days on their preadmission digoxin dosage, the numbers of patients in the 3 groups had become 8 , 30 , and 12 , respectively. The shift of patients between the groups from admission to day 8 is highly significant $\left(\chi^{2}=9.4 ; P<0.01\right)$. Of the 30 patients studied at 4 weeks, 22 had levels in the therapeutic range, 2 in the toxic range, and 6 in the subtherapeutic range. The mean plasma digoxin concentration was $1.23 \pm 0.78 \mathrm{ng} / \mathrm{ml}(1.57 \pm 0.99$ $\mathrm{nmol} / \mathrm{l}$ ). Twenty of these patients were studied again at 3 months. At this time 7 patients had levels outside the therapeutic range, 5 subtherapeutic and 2 


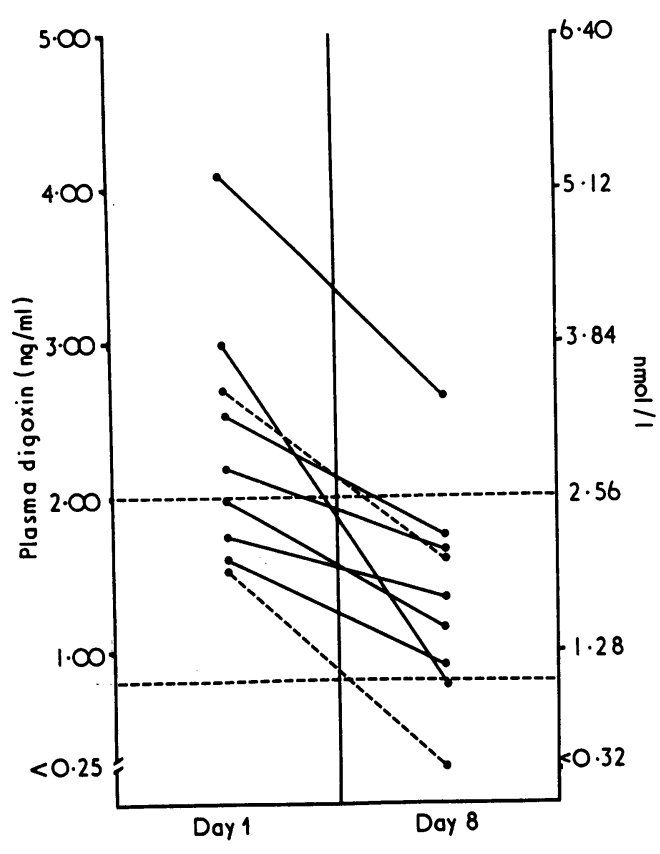

Fig. 3 Plasma digoxin concentrations in 9 patients whose levels fell from day 1 to day 8. Dotted lines indicate patients in whom renal function improved.

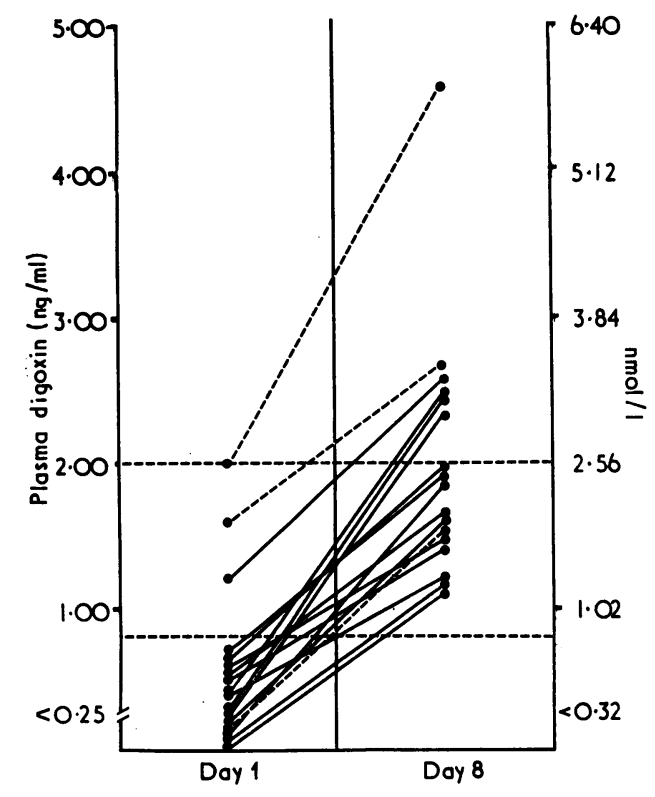

Fig. 4 Plasma digoxin concentrations in 17 patients whose levels increased from subtherapeutic to therapeutic or toxic or from therapeutic to toxic from day 1 to day 8. Dotted lines indicate patients in whom renal function deteriorated.

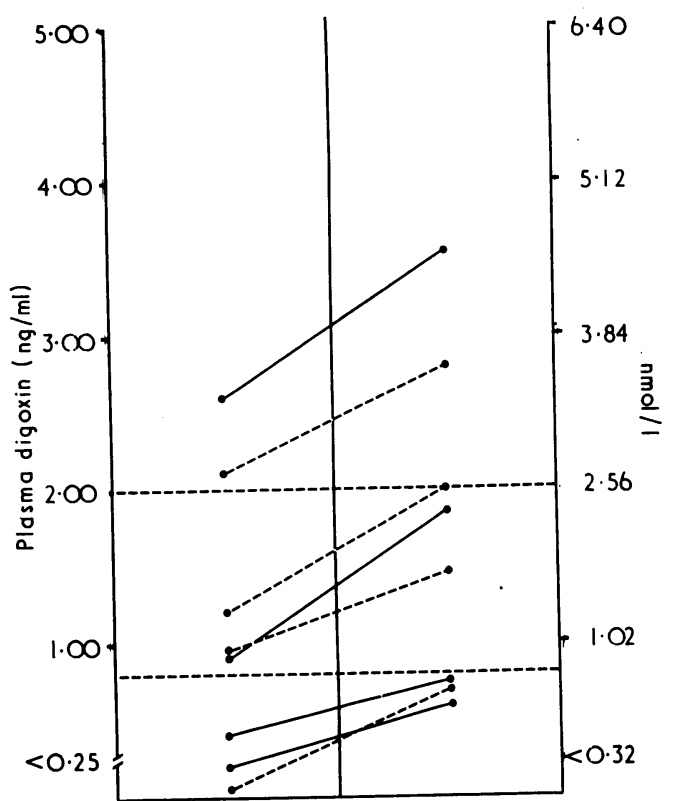

Fig. 5 Plasma digoxin concentrations in 8 patients whose levels increased from day 1 to day 8, but remained in the same range (subtherapeutic, therapeutic, or toxic). Dotted lines indicate patients in whom renal function deteriorated.

with levels greater than $2.0 \mathrm{ng} / \mathrm{ml}(2.56 \mathrm{nmol} / \mathrm{l})$ which could be explained by recent deterioration in renal function. The mean plasma digoxin concentration in this group was $1.29 \pm 1.06 \mathrm{ng} / \mathrm{ml}(1.65 \pm$ $1.36 \mathrm{nmol} / \mathrm{l})$.

On the basis of reproducibility of the laboratory methods, changes in plasma digoxin concentration of greater than $0.2 \mathrm{ng} / \mathrm{ml}(0.26 \mathrm{nmol} / \mathrm{l})$ and in serum creatinine of greater than $0.2 \mathrm{mg} / 100 \mathrm{ml}(17 \cdot 7$ $\mu \mathrm{mol} / \mathrm{l}$; were thought to represent real changes in plasma digoxin levels and in renal function, respectively. Patients who showed a change in plasma digoxin concentration from admission to day 8 , or from day 8 to either 4 weeks or 3 months, without any change in renal function, were considered to be non-compliant.

Only 16 of the original 50 patients had plasma digoxin levels which remained unchanged between day 1 and day 8 (Fig. 2). Nine patients had plasma digoxin levels which were lower on day 8 than on day 1 , but in 2 of these an improvement in renal function may have accounted for the decrease (Fig 3). The remaining 25 patients showed an increase in plasma digoxin concentration between day 1 and day 8 (Fig. 4 and 5). Fig. 4 shows 11 patients who had subtherapeutic levels on admission which became normal at day 8 , and 6 patients with toxic 
Table 2 Factors examined for relation to compliance

\begin{tabular}{|c|c|c|c|c|c|c|}
\hline Patients & No. & Age $(y) \dagger$ & $\begin{array}{l}\% \text { admitted with } \\
\text { cardiac disease }\end{array}$ & $\begin{array}{l}\% \text { claiming to be } \\
\text { taking prescribed } \\
\text { dose }\end{array}$ & $\begin{array}{l}\text { No. of digoxin } \\
\text { tablets dailyt }\end{array}$ & $\begin{array}{l}\text { Total no. of tablets } \\
\text { prescribed dailyt }\end{array}$ \\
\hline $\begin{array}{l}\text { All subjects } \\
\text { (M 23, F 27) } \\
\text { Compliant group } \\
\text { (M 14, F 11) } \\
\text { Non-compliant group } \\
\text { (M 5, F 13) }\end{array}$ & $\begin{array}{l}50 \\
25 \\
(50 \%) \\
18^{\star} \\
(36 \%)\end{array}$ & $\begin{array}{r}69.6 \\
\pm 9.9 \\
70.8 \\
\pm 11.0 \\
68.5 \\
\pm 10.9\end{array}$ & $\begin{array}{l}84 \\
76 \\
78\end{array}$ & $\begin{array}{l}78 \\
80 \\
61\end{array}$ & $\begin{array}{r}1 \cdot 26 \\
\pm 0.78 \\
1.26 \\
\pm 0.55 \\
1.22 \\
\pm 0.56\end{array}$ & $\begin{array}{r}6 \cdot 8 \\
\pm 3 \cdot 7 \\
6 \cdot 6 \\
\pm 3 \cdot 9 \\
7 \cdot 4 \\
\pm 3 \cdot 4\end{array}$ \\
\hline
\end{tabular}

$\star 7$ patients were excluded because of a significant deterioration in renal function.

+ Mean $\pm S D$.

levels on day 8 but subtherapeutic or normal levels on admission. In only 3 of these 17 patients was there a deterioration in renal function. Fig. 5 illustrates changes in plasma digoxin concentrations in the remaining 8 patients who showed an increase of more than $0.2 \mathrm{ng} / \mathrm{ml}(0.26 \mathrm{nmol} / \mathrm{l})$ while remaining within the same plasma level range. In four of these patients there was a deterioration in renal function which may have accounted for the change.

Of the 25 patients whose plasma digoxin concentration increased, 18 (36\% of total group) were, therefore, considered to be non-compliant, having shown no change in renal function to account for this increase. These patients were compared with the remaining 25 patients who were thought to be compliant, with respect to age, reason for hospital admission, patients' claim to be taking tablets as prescribed, and the number of tablets prescribed daily (Table 2). No significant differences were found between the 2 groups and as many as 61 per cent of those considered non-compliant gave a history of taking their tablets as directed. Interestingly, almost half of the women studied were thought to be non-compliant compared with only 5 out of 23 men.

Long-term outpatient compliance was assessed

Table 3 Range of serial plasma digoxin concentrations in 30 patients from day 8 to 4 weeks

\begin{tabular}{lll}
\hline $\begin{array}{l}\text { No. of patients } \\
\text { (total 30) }\end{array}$ & Day 8 & 4 weeks \\
\hline 1 & Low & Low \\
3 & Low & Normal \\
0 & Low & High \\
5 & Normal & Low \\
13 & Normal & Normal \\
2 & Normal & High \\
0 & High & Low \\
6 & High & Normal \\
0 & High & High \\
\hline
\end{tabular}

Low $=$ Plasma digoxin concentration $<0.8 \mathrm{ng} / \mathrm{ml}(1.02 \mathrm{nmol} / \mathrm{l})$. Normal = Plasma digoxin concentration 0.8 to $2.0 \mathrm{ng} / \mathrm{ml}(1.02$ to $2.56 \mathrm{nmol} / 1)$.

High $=$ Plasma digoxin concentration $>2.0 \mathrm{ng} / \mathrm{ml}(2.56 \mathrm{nmol} / \mathrm{l})$. by comparing day 8 'steady-state' plasma digoxin levels with the values obtained at 4 weeks and at 3 months. Table 3 compares day 8 with 4 week digoxin concentrations in 30 patients followed up after discharge from hospital. Of these, 22 patients had levels which remained unchanged, or on adjusted digoxin dosage were in the therapeutic range at 4 weeks. Five patients had digoxin concentrations below $0.8 \mathrm{ng} / \mathrm{ml}(1.02 \mathrm{nmol} / \mathrm{l})$ at 4 weeks, having been in the normal range at day 8 , and 3 more had levels which decreased by more than $0.2 \mathrm{ng} / \mathrm{ml}$ $(0.26 \mathrm{nmol} / \mathrm{l})$ while remaining within the therapeutic range. These 8 patients $(26.7 \%)$ were considered non-compliant as none showed any change in renal function. Of the 20 patients assessed at 3 months (Table 4), 5 had subtherapeutic digoxin levels ; 2 of these had been in the normal range at day 8 and week 4 , and the other 3 , having been in the toxic range on day 8 , had had 4-week values in the therapeutic range on adjusted digoxin dosage. One patient had digoxin levels which decreased by more than $0.2 \mathrm{ng} / \mathrm{ml}(0.26 \mathrm{nmol} / \mathrm{l})$ while remaining within the therapeutic range. Thus, at 3 months, 30 per cent of these patients were still non-compliant. Two patients, who had digoxin levels greater than $2 \cdot 0$ $\mathrm{ng} / \mathrm{ml}(2.56 \mathrm{nmol} / \mathrm{l})$, had both shown recent deterioration in renal function.

Table 4 Range of serial plasma digoxin concentrations in 20 patients from day 8 to 3 wonths

\begin{tabular}{lll}
\hline $\begin{array}{l}\text { No. of patients } \\
\text { total 20) }\end{array}$ & Day 8 & 3 months \\
\hline 0 & Low & Low \\
2 & Low & Normal \\
0 & Low & High \\
2 & Normal & Low \\
9 & Normal & Normal \\
2 & Normal & High \\
3 & High & Low \\
2 & High & Normal \\
0 & High & High \\
\hline
\end{tabular}

Low = Plasma digoxin concentration $<0.8 \mathrm{ng} / \mathrm{ml}(1.02 \mathrm{nmol} / \mathrm{l})$. Normal = Plasma digoxin concentration 0.8 to $2.0 \mathrm{ng} / \mathrm{ml}(1.02$ to $2.56 \mathrm{nmol} / 1$ ).

High $=$ Plasma digoxin concentration $>2.0 \mathrm{ng} / \mathrm{ml}(2.56 \mathrm{nmol} / \mathrm{l})$. 


\section{Discussion}

These results confirm those from our prcvious study (Carruthers et al., 1974) that on emergency admission to hospital less than half of the patients taking digoxin had plasma digoxin concentrations within the therapeutic range of 0.8 to $2.0 \mathrm{ng} / \mathrm{ml}$ $(1.02 \mathrm{nmol} / 1$ to $2.56 \mathrm{nmol} / \mathrm{l})$. Approximately onethird of the patients had concentrations below 0.8 $\mathrm{ng} / \mathrm{ml}(1.02 \mathrm{nmol} / \mathrm{l})$ and the remainder were in the potentially toxic range above $2.0 \mathrm{ng} / \mathrm{ml}(2.56$ $\mathrm{nmol} / \mathrm{l})$. These differences in plasma digoxin concentrations in patients on long-term maintenance digoxin therapy may occur not only between patients but also in individual patients over a period of several months.

The present study identifies three separate causes for this variation: non-compliance, confusion in some patients about dosage, and wrong digoxin prescribing in others. Excluding the clinically toxic patients, we concluded that 36 per cent of 50 patients were non-compliant. A further 7 patients $(14 \%)$ had plasma digoxin levels which were lower on day 8 than on admission without any improvement in renal function. Errors of dosage or timing caused by confusion or misunderstanding resulting in patients taking the drug more often than prescribed appear to be the most likely explanation in this group. Such errors may also result in patients taking too little drug but in this present study the methods of assessment used would include these in the non-compliant group. Thus 50 per cent of the patients were taking too little or too much digoxin either deliberately or because of confusion or misunderstanding about dosage. In addition, without evidence of alteration in renal function, plasma digoxin concentrations on day 8 were below $0.8 \mathrm{ng} / \mathrm{ml}(1.02 \mathrm{nmol} / \mathrm{l})$ in 6 patients and above $2.0 \mathrm{ng} / \mathrm{ml}(2.56 \mathrm{nmol} / \mathrm{l})$ in 8 patients suggesting that the wrong digoxin dosage was being prescribed in as many as 28 per cent of the total group. Several of the patients being prescribed too high a dose were also non-compliant and they were, therefore, probably protecting themselves from toxicity. Overall, subtherapeutic plasma digoxin levels on admission to hospital could be accounted for in 13 patients $(26 \%)$ by poor compliance (Fig. 4 ) and by inadequate digoxin prescribing in a further 6 patients $(12 \%)$. In two patients change in renal function from day 1 to day 8 made interpretation difficult.

Various methods have been used previously to detect drug defaulters: these include interrogation, tablet counts, drug markers, measurement of concentration of drugs in patients' urine or plasma, and analysis of prescriptions taken to pharmacists
(Blackwell, 1972). Most of these methods are open to criticism and some were not applicable to our study. We have previously found interrogation not useful (Carruthers et al., 1974) and we, therefore, decided to use a tezinique of producing 'steadystate' plas na digoxin concentrations at the patient's previous digoxin dosage, assuminz that this takes 4 to 5 half-lives for a drug from the first dose. This has the advantage of making an objective prospective measurement of compliance and we believe that this is the first time this technique has been used in a large group of patients. It is of value only for drugs with long elimination half-lives. In fact, because many of these patients had impaired renal function, the half-life of digoxin in some individuals may have been longer than 1.6 days and 'steady-state' may not have been achieved. However, in terms of patients' convenience, 7 days was considered long enough. The error, if it occurred, would have resulted in an underestimate of 'steady-state' plasma digoxin concentration and, therefore, the position may be even worse than it appeared. Another possible error of the technique is wrong assessment of what constitutes a real change in plasma digoxin concentration, but laboratory variation is said to account for only 10 per cent of a particular reading (Whiting et al., 1973) and the $0.2 \mathrm{ng} / \mathrm{ml}(0.26 \mathrm{nmol} / \mathrm{l})$ allowed may, therefore, be over-generous, again producing underestimation of the real position. In addition, as the figures show, most patients had much wider fluctuations between day 1 and day 8 .

Using this technique, significant differences were found between plasma digoxin levels on admission and on day 8 , the mean admission level being 70 per cent of that found at 'steady-state'. Interestingly, though not strictly comparable, the outpatient digoxin levels at 4 weeks and at 3 months were very similar to those obtained on admission. These findings are in agreement with those reported by Sheiner et al. (1974), who compared different groups of inpatients and outpatients, where outpatient digoxin concentrations were typically $72 \pm 16$ per cent of those derived from inpatient data. They suggested that poor compliance was the probable cause and that this was 'a consistent and predictable phenomenon'.

Estimates of patient compliance have been reported before. On the basis of history, Weintraub et al. (1973) designated 34 per cent of 101 patients taking digoxin as 'non-compliant'. However, in patients designated 'compliant' in whom serum digoxin concentrations were studied, 11 per cent had levels less than $0.5 \mathrm{ng} / \mathrm{ml}$ and digoxin was undetectable in 5.3 per cent. This raises questions about the validity of interrogation and single 
estimates of blood concentration as a method for assessing compliance. In our present study, 61 per cent of patients shown to be non-compliant by serial blood sampling claimed to be taking digoxin regularly. In a study of outpatients with tuberculosis (Maddock, 1967) followed up with multiple urine testing, both in the clinic and by random home visits, 30 per cent of 50 patients taking isoniazid and 42 per cent of 33 patients receiving aminosalicylate were found to be uncooperative. The figure for long-term compliance of 36 per cent obtained in this present study, taken with these previous estimates, suggests that something of the order of one-third of patients do not take their treatment regularly. In our experience, during 3 different periods of observation, patients who were compliant during one period were not necessarily so during the next period.

In the present study, we examined age, sex, and complexity of drug regimen as factors previously reported to influence compliance (Dixon et al., 1957; Schwartz, 1965; Gatley, 1968). Only with sex was any difference between the 2 groups apparent. Twice as many women as men were found in the defaulting group, but, as the sample was small, definite conclusions are not possible. Non-compliant patients did not appear to be admitted with cardiac disease more often than compliant ones.

Drug interaction is a possible cause of alteration in plasma digoxin concentrations: anticholinergics, metoclopramide, and spironolactone, have all been reported to change digoxin levels (Manninen et al., 1973; Steiness, 1974). However, of the 50 patients we studied, only 3 were receiving spironolactone and 1 was receiving metoclopramide on admission to hospital: these drugs were continued at their admission dosage throughout the period of observation. None of these drugs was prescribed for the first time in any other patients from day 1 to day 8 . This factor thus seems unlikely to explain the observed changes.

Several reports have recently considered the variation in biological availability of different digoxin preparations (Lindenbaum et al., 1971; Shaw et al., 1972) and even between batches of digoxin from the same drug company (Van Oudtshoorn, 1972). Initially we attempted to identify the digoxin preparation in each individual, but as many of the patients were elderly, lived alone, and could not even specify the pharmacist from whom the tablets were obtained we found comprehensive information impossible to obtain. Most patients were probably taking the same brand of digoxin before and after admission, but we have not been able to rule this out conclusively as a possible factor to account for changing plasma digoxin levels.

In the majority of studies dealing with outpatient compliance, patients have been designated fully compliant or totally non-compliant. With a drug such as digoxin with a narrow therapeutic ratio, relative degrees of non-compliance may be important. In this study 50 per cent of patients were not in a steady state consistent with their digoxin dosage and schedule, on admission to hospital, 36 per cent being non-compliant and the remainder probably confused about their dose. The important implications for further management after admission to hospital and for continuing outpatient care can only be appreciated by serial plasma digoxin concentration measurement. There was little indication that prolonged follow-up significantly improved compliance.

If these results for digoxin are in any way representative of drug compliance and patient misunderstanding about therapy generally, they have serious implications for drug prescribing and our ability to treat disease. Effective modern drugs will be of little value unless we can persuade more than half of our patients to take them properly or understand why they do not. It may be argued that these patients are not representative because they were being admitted to hospital as treatment failures, but even this interpretation cannot hide the fact that a serious and largely unappreciated problem of communication exists between patients and doctors.

\section{References}

Blackwell, B. (1972). The drug defaulter. Clinical Pharmacology and Therapeutics, 13, 841-848.

Carruthers, S. G., Kelly, J. G., and McDevitt, D. G. (1974). Plasma digoxin concentrations in patients on admission to hospital. British Heart fournal, 36, 707-712.

Chamberlain, D. A., White, R. J., Howard, M. R., and Smith, T. W. (1970). Plasma digoxin concentrations in patients with atrial fibrillation. British Medical fournal, 3, 429-432.

Dixon, W. M., Stradling, P., and Wootton, I. D. P. (1957). Out-patient P.A.S. therapy. Lancet, 2, 871-872.

Gatley, M. S. (1968). To be taken as directed. Fournal of the Royal College of General Practitioners, 16, 39-44.

Jelliffe, R. W. (1968). An improved method of digoxin therapy. Annals of Internal Medicine, 69, 703-717.

Lindenbaum, J., Mellow, M. H., Blackstone, M. O., and Butler, V. P. (1971). Variation in biologic availability of digoxin from four preparations. New England fournal of Medicine, 285, $1344-1347$.

Maddock, R. K. (1967). Patient co-operation in taking medicines. Fournal of the American Medical Association, 199, 169-172.

Manninen, V., Apajalahti, A., Melin, J., and Karesoja, M. (1973). Altered absorption of digoxin in patients given propantheline and metoclopramide. Lancet, 1, 398-400.

Ojala, K., Karjalainen, J., and Reissell, P. (1972). Radioimmunoassay of digoxin. Lancet, $1,150$.

Schwartz, D. (1965). The elderly patient and his medications. Geriatrics, 20, 517-520. 
Shaw, T. R. D., Howard, M. R., and Hamer, J. (1972). Variation in the biological availability of digoxin. Lancet, 2, 303-307.

Sheiner, L. B., Rosenberg, B., Marathe, V. V., and Peck, C. (1974). Differences in serum digoxin concentrations between outpatients and inpatients. An effect of compliance. Clinical Pharmacology and Therapeutics, 15, 239-246.

Steiness, E. (1974). Renal tubular secretion of digoxin. Circulation, 50, 103-107.

Van Oudtshoorn, M. C. B. (1972). Bioavailability of digoxin. Lancet, 2, 1153-1154.

Weintraub, M., Au, W. Y. W., and Lasagna, L. (1973).
Compliance as a determinant of serum digoxin concentration. Fournal of the American Medical Association, 224, 481-485.

Whiting, B., Sumner, D. J., and Goldberg, A. (1973). An assessment of digoxin radioimmunoassay. Scottish Medical Fournal, 18, 69-74.

Requests for reprints to Dr. D. G. McDevitt, Department of Therapeutics and Pharmacology, Whitla Medical Building, 97 Lisburn Road, Belfast BT9 7BL. 